\title{
Impairment of jejunal absorption rate of carnosine by glycylglycine in man in vivo
}

\author{
G. C. COOK \\ From the Department of Medicine, The University of Zambia, Lusaka, Zambia
}

SUMMARY Using a double-lumen tube jejunal perfusion system in vivo, the mutual effects of carnosine ( $\beta$-alanyl-L-histidine) and glycylglycine on their respective absorption rates have been studied in six Zambian African adults. Data on the effect of the constituent amino-acids of carnosine on glycylglycine absorption rate have similarly been obtained. The solutions infused in each subject contained (A) carnosine $\left(50 \mathrm{mmol} \mathrm{l} .^{-1}\right),(B)$ carnosine $\left(50 \mathrm{mmol} \mathrm{l}^{-1}\right)$ and glycylglycine $(50 \mathrm{mmol}$ $\left.1 .^{-1}\right)$, (C) glycylglycine $\left(50 \mathrm{mmol} \mathrm{l}^{-1}\right)$, and (D) glycylglycine $\left(50 \mathrm{mmol} \mathrm{l}^{-1}\right)$, L-histidine $(50 \mathrm{mmol}$ $\left.1 .^{-1}\right)$ and $\beta$-alanine $\left(50 \mathrm{mmol} \mathrm{l}^{-1}\right)$. Glycylglycine produced a significant impairment in the mean rate of histidine absorption from carnosine $(P<0.01)$. However, carnosine did not have a significant effect on the mean rate of glycine absorption from glycylglycine. Mean rate of histidine absorption from solution $\mathrm{D}$ was significantly higher than that from solution $\mathrm{A}(\mathrm{P}<0.01)$. Mean rate of glycine absorption from glycylglycine was not significantly different during infusion of solutions B, C, and D. The results are consistent with the concept that carnosine and glycylglycine share the same transfer mechanism; the lack of influence of carnosine on glycylglycine is probably because the affinity of carnosine for the dipeptide uptake mechanism is relatively low. A gross difference has been shown between mean absorption rate of histidine from free L-histidine (solution D) $\left(25.8 \mathrm{mmol} \mathrm{h}^{-1}\right)$ and when it is given in the form of carnosine in the presence of another dipeptide (solution B) (8.7 $\mathrm{mmol} \mathrm{h}-1$ ); that emphasizes the complexity of amino acid and peptide interaction during absorption, which must be important in nutrition.

Dipeptides and their constituent amino acids are absorbed at different rates and use transfer mechanisms that are partly and possibly wholly separate. That applies both to experimental animals (Newey and Smyth, 1959, 1960; Matthews et al., 1968; Matthews, 1971, 1972) and man (Craft et al., 1968; Asatoor et al., 1970; Adibi, 1971; Cook, 1972, 1973, 1974a, b; Hellier et al., 1972).

Evidence that some peptides share a common transfer mechanism, or mechanisms, is limited, but that now seems certain from in vitro experiments in animals (Rubino et al., 1971; Addison et al., 1972; Addison et al., 1974; Matthews et al., 1974).

In the present investigation, the mutual effects of the dipeptides carnosine ( $\beta$-alanyl-L-histidine) and glycylglycine on their respective absorption rates have been studied in man in vivo using a doublelumen tube jejunal perfusion system. The effect of L-

Address for correspondence and reprint requests: G. C. Cook, Medical Unit, Hospital for Tropical Diseases, 4, St. Pancras Way, London NW1 OPE.

Received for publication 14 January 1976 histidine in the presence of $\beta$-alanine on glycylglycine absorption rate has also been studied.

\section{Methods}

Table 1 gives clinical and laboratory details of six Zambian African subjects investigated. They were all inpatients at the University Teaching Hospital, Lusaka. None had previously been studied. They agreed to undergo investigation after the procedure had been explained through an interpreter. None of them had clinical evidence of gastrointestinal disease; one of them (no. 4) was clinically malnourished. Methods for serum protein determination and Dxylose absorption have been described by Cook (1974a).

\section{PROCEDURE AND INVESTIGATIONS}

The technique of jejunal perfusion has been described by Cook (1971). Table 1 shows the position of the proximal opening of the double-lumen tube at the beginning of the investigation (Cook and Carruthers, 


\begin{tabular}{|c|c|c|c|c|c|c|c|c|c|c|c|c|c|}
\hline \multirow{2}{*}{$\begin{array}{l}\text { Subject } \\
\text { no. }\end{array}$} & \multirow{2}{*}{$\operatorname{Sex}$} & \multirow{2}{*}{$\begin{array}{l}\text { Age } \\
(y r)\end{array}$} & \multirow[t]{2}{*}{ Tribe* } & \multirow{2}{*}{$\begin{array}{l}\text { Body } \\
w t \\
(k g)\end{array}$} & \multirow{2}{*}{$\begin{array}{l}\text { Clinical } \\
\text { diagnosis }\end{array}$} & \multirow{2}{*}{$\begin{array}{l}\text { Haemo- } \\
\text { globin } \\
\left(\mathrm{g} l .^{-1}\right)\end{array}$} & \multicolumn{3}{|c|}{ Serum protein $\left(\mathrm{g} l .^{-1}\right)$} & \multirow{2}{*}{$\begin{array}{l}\text { D-xylose } \\
\text { excretion } \\
\left(g .5 h^{-1}\right)\end{array}$} & \multirow{2}{*}{$\begin{array}{l}\text { Stool } \\
\text { parasites }\end{array}$} & \multirow{2}{*}{$\begin{array}{l}\text { Tube } \\
\text { position } \dagger\end{array}$} & \multirow{2}{*}{$\begin{array}{l}\text { Sequence of } \\
\text { perfusions }\end{array}$} \\
\hline & & & & & & & Albumin & $\begin{array}{l}\text { Total } \\
\text { globulin }\end{array}$ & $\begin{array}{l}\gamma- \\
\text { globulin }\end{array}$ & & & & \\
\hline 1 & $\mathbf{M}$ & 33 & Nsenga & 54 & $\begin{array}{l}\text { Tuberculous } \\
\text { cervical lympha- } \\
\text { denopathy }\end{array}$ & 145 & 40 & 44 & 24 & $6 \cdot 1$ & Nil & 25 & CABD \\
\hline 2 & $\mathbf{F}$ & 49 & Chewa & 60 & $\begin{array}{l}\text { Mild essential } \\
\text { hypertension }\end{array}$ & 89 & 41 & 51 & 28 & $5 \cdot 2$ & $\begin{array}{l}\text { Hook- } \\
\text { worm and } \\
\text { Shisto- } \\
\text { soma } \\
\text { mansoni }\end{array}$ & $d^{32}$ & DABC \\
\hline 3 & $\mathbf{M}$ & 18 & Lambya & 46 & $\begin{array}{l}\text { Polyarthropathy } \\
\text { of unknown } \\
\text { aetiology }\end{array}$ & 116 & 35 & 55 & 30 & $6 \cdot 3$ & Nil & 22 & CBDA \\
\hline 4 & $\mathbf{M}$ & 18 & Ngoni & 46 & $\begin{array}{l}\text { Bilateral cavitat- } \\
\text { ing pulmonary } \\
\text { tuberculosis }\end{array}$ & 103 & 24 & 52 & 25 & $3 \cdot 3$ & Nil & 24 & DCBA \\
\hline 5 & $\mathbf{M}$ & 22 & Mambwe & 53 & $\begin{array}{l}\text { Right upper lobar } \\
\text { pneumonia } \\
\text { (probably } \\
\text { tuberculous) }\end{array}$ & 162 & 35 & 48 & 22 & $5 \cdot 1$ & Nil & 14 & $A B C D$ \\
\hline 6 & $\mathbf{F}$ & 45 & Nsenga & 70 & $\begin{array}{l}\text { Bronchial asthma } \\
\text { (recovered) }\end{array}$ & 157 & 42 & 39 & 18 & $9 \cdot 8$ & $\begin{array}{l}\text { Hook- } \\
\text { worm }\end{array}$ & 13 & BDAC \\
\hline
\end{tabular}

Table 1 Details of subjects studied

*Brelsford (1965).

†Distance of proximal opening past duodenojejunal flexure $(\mathrm{cm})$ at start of investigation.

$\ddagger \mathbf{A}=$ carnosine; $\mathbf{B}=$ carnosine + glycylglycine; $\mathbf{C}=$ glycylglycine; $\mathbf{D}=$ glycylglycine $+\mathrm{L}$-histidine $+\beta$-alanine

1974). A second radiograph was taken at the end of the investigation and the perfusion segment had not moved by more than 8 (mean 5 ) cm distally in relation to the duodenojejunal flexure.

Perfusion was with (A) a $50 \mathrm{mmol} \mathrm{1.-1}(11.30 \mathrm{~g}$ $1 .^{-1}$ ) carnosine solution (it was obtained in subjects 1 and 2 from Koch-Light Ltd, England, and in subjects 3-6 from the British Drug Houses Ltd, England); (B) a $50 \mathrm{mmol} \mathrm{1.-1}$ carnosine and 50 mmoll. ${ }^{-1}\left(6.60 \mathrm{~g}^{1} .^{-1}\right)$ glycylglycine (Koch-Light Ltd, England) solution; (C) a $50 \mathrm{mmol} 1 .^{-1}$ glycylglycine solution; and (D) a $50 \mathrm{mmol} 1 .^{-1}$ glycylglycine, 50 mmol 1. ${ }^{-1}\left(7.75 \mathrm{~g} \mathrm{l}^{-1}\right)$ L-histidine (KochLight Ltd, England) and $50 \mathrm{mmol} 1 .^{-1}\left(4.45 \mathrm{~g} \mathrm{l}^{-1}\right)$ $\beta$-alanine (Koch-Light Ltd, England) solution. All solutions were made iso-osmotic $\left(300 \mathrm{mmol} \mathrm{l}^{-1}\right)$ with sodium chloride and they all contained $5.0 \mathrm{~g} \mathrm{l} .^{-1}$ polyethylene glycol (PEG) 4000 as a non-absorbable marker. The sequence of the perfusions was varied in the different subjects (Table 1). Perfusion with the four solutions followed directly after each other.

In order to determine whether intact dipeptides were present in the peripheral blood during infusions containing carnosine and glycylglycine, venous blood samples were obtained at the mid-point of each collection period-that is, 50 minutes after the start of each perfusion. After heparinization, plasma was immediately separated and diluted $1: 1$ with $6 \%$ sulphosalicylic acid; supernatant fluid was transported by air to London where chromatographic quantitation of amino acids and peptides was performed as previously described (Matthews et al., 1974).

Aliquots of intestinal content were frozen solid as soon as they were obtained, together with samples of the perfusion solutions. L-histidine (free or in the form of carnosine) concentrations were determined by the method of Macpherson (1946); the standard curve for carnosine (solution A) gave spectrophotometer OD readings which were approximately $5 \%$ higher than for its equivalent as free L-histidine (solution D). A $50 \mathrm{mmol} 1 .^{-1} \beta$-alanine solution gave zero values for $L$-histidine. Separate standard curves for all perfusion solutions were used at each determination. In subjects 1 and 2, L-histidine was also determined after hydrolysis; samples of all perfusion solutions and intestinal samples were heated in sealed tubes with 3 vol $6 \mathrm{M}-\mathrm{HCl}$ at $110^{\circ} \mathrm{C}$ for $16 \mathrm{~h}$. The results were identical with those obtained on the same specimens before hydrolysis. Glycine was determined by the method of Giroux and Puech (1963), and glycylglycine by the same method after hydrolysis in sealed tubes with 2 vol $6 \mathrm{M}-\mathrm{HCl}$ at $110^{\circ} \mathrm{C}$ for $16 \mathrm{~h}$. PEG was estimated by the turbidimetric method of Hydén(1955). Determinations were made on all perfusion solutions and samples of intestinal content obtained during those perfusions, at the same time; glycine and glycylglycine were estimated in triplicate, and L-histidine (free or in the form of carnosine) and PEG in duplicate. 


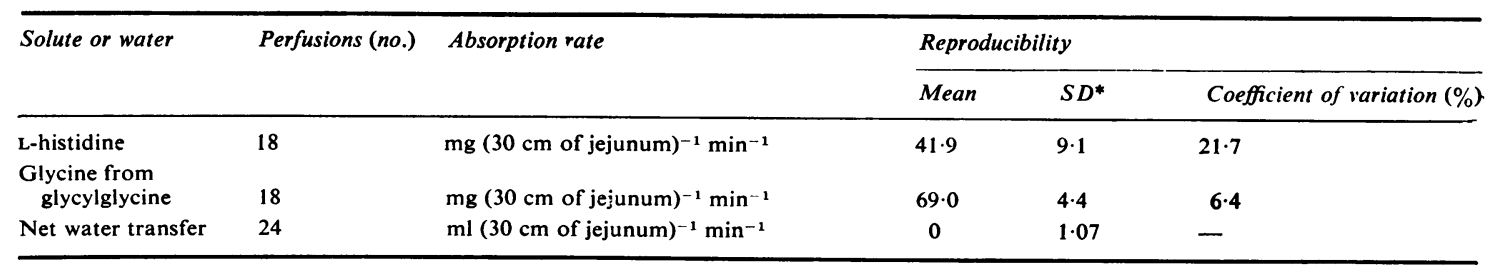

Table 2 Reproducibility of absorption rates for three 10-minute collections of intestinal content during each perfusion *Cook (1974a).

Histidine determinations on solution $\mathrm{C}$ gave results which were all $<2 \mathrm{mmol} 1 .^{-1}$ (expressed as free histidine). Analysis of intestinal samples obtained during perfusion of solution $\mathrm{C}$ gave a mean free histidine concentration of $6 \mathrm{mmol} \mathrm{l}^{-1}$; all were $<17$ mmol l. ${ }^{-1}$.

Free glycine determinations-that is, before hydrolysis-on solutions B, C, and D gave concentrations of approximately $6 \mathrm{mmol} \mathrm{l}^{-1}$. Free glycine determinations on solution A gave a mean concentration of $1 \mathrm{mmol} \mathrm{1.-1}$ and after hydrolysis $3 \mathrm{mmol} \mathrm{1.-1}$. Analysis of intestinal samples obtained during perfusion of solution A (after hydrolysis) for glycine gave a mean result of $3 \mathrm{mmol} \mathrm{l}^{-1}$; all results were $<12 \mathrm{mmol} \mathrm{l}^{-1}$

The absorption rates of $L$-histidine (from solutions A, B, and D), glycine (from solutions B, C, and D) and net water transfer rates were calculated as described by Cook (1971). Table 2 summarizes the reproducibility of the results for the three $10 \mathrm{~min}$ collections during each perfusion (Cook, 1974a).

\section{Results}

Figure 1 summarizes absorption rate of L-histidine from solutions A, B, and D. Mean absorption rate from solution $B$ is significantly lower than that from solution $\mathrm{A}(t=4.100 ; d . f .=5 ; \mathrm{P}<0.01$; paired $t$ test). Mean absorption rate from solution $D$ is significantly higher than that from solution $\mathbf{A}(t=$ $6.501 ;$ d.f. $=5 ; \mathrm{P}<0.01$; paired $t$ test $)$ and that from solution $\mathrm{B}(t=16.231 ;$ d.f. $=5$; $\mathrm{P}<0.001$; paired $t$ test). Subject 6 had the highest and subject 2 the lowest rate of L-histidine absorption from solution $\mathrm{A}$. The three subjects with the highest Lhistidine absorption rates from solution $D$ were nos. 4,5 , and 6.

Figure 2 summarizes absorption rates of glycine from glycylglycine in solutions B, C, and D. Mean absorption rates from the glycylglycine in solutions $C$ and $B$ are not significantly different $(t=0.667$; d.f. $=5 ; \mathrm{P}<0.60$; paired $t$ test). Mean absorption rates from the glycylglycine in solutions $\mathrm{C}$ and $\mathrm{D}$ are not significantly different $(t=0.653 ;$ d.f. $=5$; $\mathrm{P}<0.60$; paired $t$ test). Mean absorption rates from the glycylglycine in solutions $\mathrm{B}$ and $\mathrm{D}$ are also not significantly different $(t=0.591 ;$ d.f. $=5$; $\mathbf{P}<0.60$; paired $t$ test). The lowest absorption rates from solution $B$ were in subjects 1 and 2 .
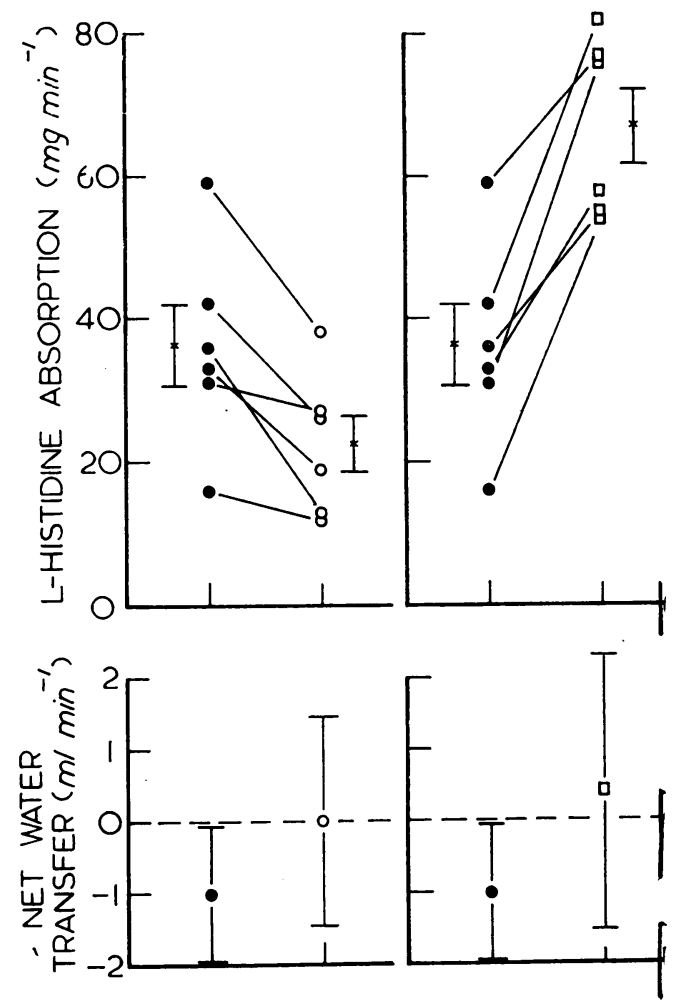

Fig. 1 L-histidine absorption rate $(m g(30 \mathrm{~cm}$ of jejunum $)^{-1}$ min $^{-1}$ ) from the jejunum of six Zambian African subjects. Absorption rate from solutions $A$ (carnosine) (O), B (carnosine + glycylglycine) $(\bigcirc)$, and $D$ (L-histidine $+\beta$-alanine + glycylglycine $)(\square)$ are shown with the means \pm ISEM. Mean L-histidine absorption rate from solution $B$ is significantly lower than that from solutions $A$ and $D$; mean absorption rate from solution $A$ is also significantly lower than that from solution $D$. Mean net water transfer rate $(\mathrm{ml}(30$ cm of jejunum) ${ }^{-1}$ min $^{-1}$ ) from solutions $A(O), B(\bigcirc)$ and $D(\square) \pm I S E M$ are also shown. Differences between means are not significant. 

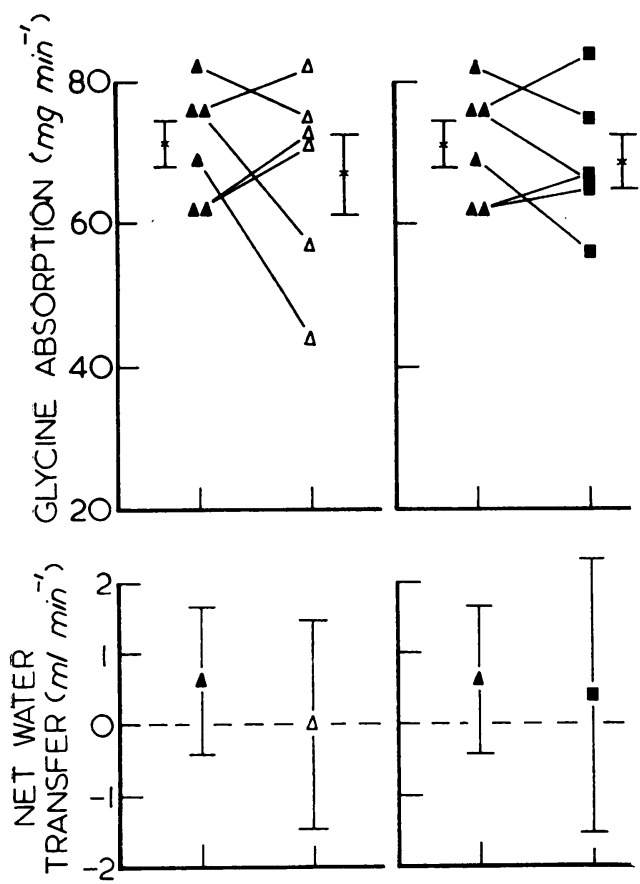

Fig. 2 Glycine absorption rate ( $\mathrm{mg}(30 \mathrm{~cm} \text { of jejunum })^{-1}$ min $^{-1}$ ) from the jejunum of six Zambian African subjects. Absorption rate from glycylglycine in solutions $C$ (glycylglycine) ( $\Delta), B$ (glycylglycine + carnosine $)$ $(\triangle)$, and $D$ (glycylglycine + L-histidine $+\beta$-alanine $)$ (घ) are shown with the means $\pm I S E M$. Differences between mean absorption rate from the three solutions are not significant. Mean net water transfer rate $\left(\mathrm{ml}(30 \mathrm{~cm} \text { of jejunum })^{-1} \mathrm{~min}^{-1}\right)$ from solutions $C(\mathbf{\Delta})$, $B(\triangle)$ and $D(\square) \pm I S E M$ are also shown. Differences between means are not significant.

Figures 1 and 2 summarize net water transfer rate from solutions A, B, C, and D. None of the differences is significant (paired and unpaired $t$ test).

Mean luminal disappearance rate of glycylglycine ( $\mathrm{mg}$ glycine $(30 \mathrm{~cm} \text { of jejunum })^{-1} \mathrm{~min}^{-1}$ ) from solutions $\mathrm{C}, \mathrm{B}$, and $\mathrm{D}$ was higher than glycine absorption rate by $8(t=2.331 ; d . f .=5 ; \mathrm{P}<0 \cdot 10$; paired $t$ test $)$, $13(t=2.827 ;$ d.f. $=5 ; \mathrm{P}<0.05$; paired $t$ test $)$, and $17(t=2.540 ;$ d.f. $=5 ; \mathrm{P}<0.10 ;$ paired $t$ test $)$ $\%$ respectively.

Table 3 gives plasma concentrations of amino acids and peptides during the perfusions. Carnosine could not be detected in any of the specimens; however, glycylglycine was present in most of them. Solution $\mathrm{C}$ was perfused first in subjects 1 and 3 ; although no $\beta$-alanine could be detected, histidine was present in both. Solution A was perfused first in subject 5; although no glycylglycine was detectable, glycine was present. During infusion of solution D, glycylglycine was present at a higher concentration compared with $\mathrm{A}, \mathrm{B}$, and $\mathrm{C}$ in all of the subjects, despite the order of the perfusions; that difference is significant. None of the other differences in concentrations between subjects or solutions was significant.

All of the subjects passed two or three stools either during or soon after completion of the investigation. Subjects 3 and 4 complained of nausea during perfusion of solution $A$, and subjects 2 and 6 during perfusion of solution B. No other symptoms, including parasthesiae (Asatoor et al., 1970), were reported despite careful questioning.

\section{Discussion}

This investigation shows that glycylglycine significantly impairs the rate of L-histidine absorption from carnosine when the two peptides are given at concentrations of $50 \mathrm{mmol} \mathrm{1.}^{-1}$ in man in vivo. Mean Lhistidine absorption rate from solution $\mathrm{A}$ was 13.8 and that from solution B $8.7 \mathrm{mmol}(30 \mathrm{~cm}$ of jejunum) $)^{-1} \mathrm{~h}^{-1}$. The mean absorption rate of glycine from glycylglycine (mean rate from solutions $\mathrm{C}$, B, and D was $55.2 \mathrm{mmol}(30 \mathrm{~cm} \text { of jejunum })^{-1}$ $\mathrm{h}^{-1}$ ) was not, however, significantly altered by carnosine. The result of the study is consistent with the possibility that glycylglycine and carnosine share the same transfer mechanism. The affinity of carnosine for the dipeptide uptake mechanism is likely to be relatively low due to the fact that it contains a $\beta$ amino acid; lack of impairment of glycine absorption from glycylglycine may also be partly due to its considerably higher absorption rate compared with carnosine. Addison et al. (1974) have shown in the hamster jejunum in vitro that carnosine transfer exhibits saturation kinetics and is inhibited by several peptides including glycylglycine; transfer was not, however, inhibited by L-histidine and $\beta$ alanine. A previous investigation in man has shown that L-histidine and glycylglycine are transported by separate mechanisms (Cook, 1974a).

The present investigation also shows that in man in vivo, free $\mathrm{L}$-histidine (in the presence of $\beta$-alanine) is transported across the jejunal mucosa at a significantly greater rate than L-histidine in the form of carnosine. That finding is consistent with the observation that oral $\mathrm{L}$-histidine and $\beta$-alanine produce higher serum amino acid concentrations than carnosine when given in equivalent amounts (Asatoor et al., 1970). Those authors concluded, by similarly investigating a patient with Hartnup disease, that carnosine is taken up by the enterocyte as the dipeptide, but that subsequent hydrolysis and delivery of the amino acids to portal blood was 


\begin{tabular}{|c|c|c|c|c|c|c|}
\hline \multirow{2}{*}{$\begin{array}{l}\text { Plasma concentration } \\
\left(\mu \mathrm{mol} \mathrm{l}^{-1}\right)\end{array}$} & \multicolumn{6}{|c|}{ Subject no. } \\
\hline & 1 & 2 & 3 & 4 & 5 & 6 \\
\hline \multicolumn{7}{|l|}{ Carnosine } \\
\hline A & 0 & 0 & $\mathbf{0}$ & $\mathbf{0}$ & 0 & 0 \\
\hline $\mathbf{B}$ & 0 & $\mathbf{0}$ & $\mathbf{0}$ & $\mathbf{0}$ & 0 & $\mathbf{0}$ \\
\hline C & $\mathbf{0}$ & $\mathbf{0}$ & 0 & $\mathbf{0}$ & 0 & $\mathbf{0}$ \\
\hline D & 0 & 0 & 0 & 0 & 0 & 0 \\
\hline A & 321 & 1324 & 499 & 307 & 308 & 1020 \\
\hline $\mathbf{B}$ & 546 & 1221 & 347 & 267 & 343 & 1051 \\
\hline C & 84 & 1134 & 46 & 377 & 252 & 1445 \\
\hline D & 1212 & 1145 & 581 & 268 & 366 & 1679 \\
\hline \multicolumn{7}{|l|}{$\beta$-alanine } \\
\hline $\mathbf{A}$ & 247 & 750 & 326 & 308 & 288 & 2097 \\
\hline B & 675 & 991 & 281 & 159 & 386 & 1101 \\
\hline C & 0 & 987 & 0 & 234 & 270 & 1570 \\
\hline D & 1365 & 732 & 703 & 236 & 226 & 1972 \\
\hline A & $\mathbf{0}$ & 91 & 18 & 13 & 0 & 153 \\
\hline $\mathbf{B}$ & 19 & 74 & 32 & 50 & 31 & 86 \\
\hline C & 0 & 72 & 0 & 99 & 25 & 86 \\
\hline D & 167 & 523 & 179 & 134 & 93 & 363 \\
\hline \multicolumn{7}{|l|}{ Glycine } \\
\hline $\mathbf{A}$ & 732 & 1694 & 988 & 882 & 189 & 2129 \\
\hline B & 1442 & 2387 & 1189 & 1210 & 633 & 1733 \\
\hline $\mathrm{C}$ & 1254 & 2964 & 843 & 1187 & 942 & 2112 \\
\hline D & 2117 & 2068 & 1560 & 635 & 1180 & 2479 \\
\hline
\end{tabular}

Table 3 Plasma concentrations of carnosine and glycylglycine and their constituent amino acids during jejunal perfusions in six subjects

*The mean concentration during the infusion of solution D is significantly higher than that during infusion of solution $\mathbf{A}(t=2 \cdot 73 ; \mathbf{P}<0.05)$ $\mathrm{B}(t=2.84 ; \mathrm{P}<0.02)$, and $\mathrm{C}(t=2.80 ; \mathrm{P}<0.02)$ (Student's $t$ test).

slower from the peptide than from its free amino acids.

Although intact glycylglycine was detected in peripheral blood during the perfusions in all of the subjects, carnosine could not be demonstrated. A significantly higher mean plasma concentration of glycylglycine has been demonstrated during the infusion of glycylglycine, histidine, and $\beta$ alanine (solution $D$ ) compared with solutions containing either glycylglycine (solution C), or glycylglycine and carnosine (solution B) (Table 3). Because of the relatively rapid sequence of the perfusions, residual plasma concentrations from previous infusion solutions have complicated those results, but that difference is clear and is similar to the inhibitory effect of L-histidine and L-methionine on the hydrolysis of glycylglycine (Cheeseman et al., 1971) and glycylsarcosine (Addison et al., 1972) during absorption in animal experiments in vitro.

A gross difference has been demonstrated in the present study between L-histidine absorption rate from free L-histidine $(25.8 \mathrm{mmol}(30 \mathrm{~cm}$ of jejunum $)^{-1} h^{-1}$ ) in the presence of $\beta$-alanine, and Lhistidine in the form of carnosine in the presence of glycylglycine $\left(8.7 \mathrm{mmol}(30 \mathrm{~cm} \text { of jejunum })^{-1} \mathrm{~h}^{-1}\right)$ when given in equivalent concentrations. That observation emphasizes the difficulty in calculating amino acid absorption rates from dietary compo- nents. The difficulty in predicting the correct dietary combination of amino acids and peptides to produce ideal blood concentrations for efficient hepatic protein synthesis is also clear. Relatively slow absorption rate of some peptides-for example, carnosine-in the presence of other peptides may partly explain the 'reserve' absorptive area of the human small intestine. A recent investigation has demonstrated that because of marked 'concertinaing' (or gathering) of the human small intestine over the polyvinyl tube the segment perfused is considerably greater than $30 \mathrm{~cm}$ (Cook and Carruthers, 1974). That suggests that the present findings are applicable to a substantial portion of the small intestine, including the proximal region where protein absorption is probably largely completed.

Ideally, five perfusions should have been made in the present study; the fifth solution should have contained carnosine (50 mmol $\left.1 .^{-1}\right)$ and glycine (100 mmol 1. ${ }^{-1}$ ). However, the length of time taken and the high cost of carnosine had to be taken into account in the planning of the investigation. The reproducibility of L-histidine absorption rate (Table 2) was less good than in previous experiments using the same perfusion system. That was due largely to the low mean L-histidine absorption rate from solutions $\mathbf{A}$ and $\mathbf{B}$. L-histidine concentration in the intestinal samples during perfusion of solution $\mathrm{C}$ 
(glycylglycine) was relatively high in some subjects; that was presumably due to the persistence of carnosine in the intestinal lumen from the previous perfusions as a result of the low rate of carnosine absorption. In further studies on compounds which are very slowly absorbed a greater length of time than $35 \mathrm{~min}$ is recommended for equilibration.

I am grateful to $\mathrm{Mr}$ James Tembo for his help in explaining the procedure to the six Zambian subjects. Dr David Burston (Department of Experimental Chemical Pathology, Westminster Hospital, London) kindly examined the plasma samples chromatographically for amino acids and dipeptides. The Reverend W. H. Woodhouse provided generous financial support.

\section{References}

Addison, J. M., Burston, D., and Matthews, D. M. (1972) Evidence for active transport of the dipeptide glycylsarcosine by hamster jejunum in vitro. Clinical Science, 43, 907-911.

Addison, J. M., Matthews, D. M., and Burston, D. (1974). Competition between carnosine and other peptides for transport by hamster jejunum in vitro. Clinical Science and Molecular Medicine, 46, 707-714.

Adibi, S. A. (1971). Intestinal transport of dipeptides in man: relative importance of hydrolysis and intact absorption. Journal of Clinical Investigation, 50, 2266-2275.

Asatoor, A. M., Bandoh, J. K., Lant, A. F., Milne, M. D., and Navab, F. (1970). Intestinal absorption of carnosine and its constituent amino acids in man. Gut, 11, 250-254.

Asatoor, A. M., Cheng, B., Edwards, K. D. G., Lant, A. F., Matthews, D. M., Milne, M. D., Navab, F., and Richards, A. J. (1970). Intestinal absorption of two dipeptides in Hartnup disease. Gut, 11, 380-387.

Brelsford, W. V. (1965). The Tribes of Zambia. Government Printer: Lusaka.

Cheeseman, C. I., Newey, H., and Smyth, D. H. (1971). Effect of amino acids on the hydrolysis of dipeptides by rat small intestine. Journal of Physiology, 212, 25P-26P.

Cook, G. C. (1971). Impairment of glycine absorption by glucose and galactose in man. Journal of Physiology, 217, $61-70$.

Cook, G. C. (1972). Comparison of intestinal absorption rates of glycine and glycylglycine in man and the effect of glucose in the perfusing fluid. Clinical Science, 43, 443-453. Cook, G. C. (1973). Independent jejunal mechanisms for glycine and glycylglycine transfer in man in vivo. British Journal of Nutrition, 30, 13-19.

Cook, G. C. (1974a). Effect of glycylglycine and glycine on jejunal absorption rate of L-histidine in man in vivo. Journal of Physiology, 237, 187-194.

Cook, G. C. (1974b). Effect of systemic infections on glycylglycine absorption rate from the human jejunum in vivo. British Journal of Nutrition, 32, 163-167.

Cook, G. C., and Carruthers, R. H. (1974). Reaction of human small intestine to an intraluminal tube and its importance in jejunal perfusion studies. Gut, 15, 545-548.

Craft, I. L., Geddes, D., Hyde, C. W., Wise, I. J., and Matthews, D. M. (1968). Absorption and malabsorption of glycine and glycine peptides in man. Gut, 9, 425-437.

Giroux, J., and Puech, A. (1963). Nouvelle méthode de dosage du glycocolle. Annales Pharmaceutiques Françaises, 21, 469-476.

Hellier, M. D., Holdsworth, C. D., Perrett, D., and Thirumalai, C. (1972). Intestinal dipeptide transport in normal and cystinuric subjects. Clinical Science, 43, 659-668.

Hydén, S. (1955). A turbidimetric method for the determination of higher polyethylene glycols in biological materials. Kungliga Lantbruks högskolxus Annaler, 22, 139 145.

Macpherson, H. T. (1946). The basic amino-acid content of proteins. Biochemical Journal, 40, 470-481.

Matthews, D. M. (1971). Protein absorption. Journal of Clinical Pathology, 24, suppl. 5, 29-40.

Matthews, D. M. (1972). Rates of peptide uptake by small intestine. In Peptide Transport in Bacteria and Mammalian Gut, pp. 71-88. Edited by K. Elliott, and M. O'Connor. Elsevier: Amsterdam.

Matthews, D. M., Craft, I. L., Geddes, D. M., Wise, I. J., and Hyde, C. W. (1968). Absorption of glycine and glycine peptides from the small intestine of the rat. Clinical Science, 35, 415-424.

Matthews, D. M., Addison, J. M., and Burston, D. (1974). Evidence for active transport of the dipeptide carnosine $(\beta$-alanyl-L-histidine) by hamster jejunum in vitro. Clinical Science and Molecular Medicine, 46, 693-705.

Newey, H., and Smyth, D. H. (1959). The intestinal absorption of some dipeptides. Journal of Physiology, 145, 48-56.

Newey, H., and Smyth, D. H. (1960). Intracellular hydrolysis of dipeptides during intestinal absorption. Journal of Physiology, 152, 367-380.

Rubino, A., Field, M., and Shwachman, H. (1971). Intestinal transport of amino acid residues of dipeptides. I. Influx of the glycine residue of glycyl-L-proline across mucosal border. Journal of Biological Chemistry, 246, 3542-3548. 